\title{
Luteolytic potency of a prostaglandin analogue at different stages of the oestrous cycle in red deer (Cervus elaphus) hinds
}

\author{
G. W. Asher ${ }^{1}$, M. W. Fisher ${ }^{1}$, D. K. Berg ${ }^{2}$, F. A. Veldhuizen ${ }^{2}$ and \\ C. J. Morrow ${ }^{3}$ \\ ${ }^{1}$ AgResearch, Invermay Agricultural Centre, Private Bag 50034, Mosgiel, New Zealand; ${ }^{2}$ AgResearch, \\ Ruakura Agricultural Centre, Private Bag 3123, Hamilton, New Zealand; and ${ }^{3}$ National Zoological Park, \\ Conservation and Research Centre, Smithsonian Institution, Front Royal, VA 22630, USA
}

\begin{abstract}
The luteolytic effect of the prostaglandin $\mathrm{F}_{2 \alpha}$ analogue, cloprostenol, was investigated in red deer by monitoring concentrations of plasma progesterone, the induction of oestrus and ovulation, and fertility. Oestrus was synchronized in 48 adult hinds by intravaginal delivery of exogenous progesterone for 12 days and i.m. injection of 250 iu pregnant mares' serum gonadotrophin at progesterone withdrawal. A single i.m. dose of $500 \mu \mathrm{g}$ cloprostenol was administered at day $4,6,8,10,12,14$ or 16 of the subsequent oestrous cycle $(n=6$ hinds per treatment; day $0=$ oestrus). Six other hinds were monitored by intensive collection of blood samples between day 16 and day 19 to define changes in plasma progesterone concentrations during spontaneous luteolysis. Samples of jugular blood, collected every second day throughout the study and every $6 \mathrm{~h}$ for $78 \mathrm{~h}$ from the time of administration of cloprostenol, were analysed for plasma concentrations of progesterone and LH. Oestrus was detected by continuous observation during the period of intensive collection of blood samples and all hinds were subjected to transrectal ultrasonography to assess pregnancy status. On the basis of changes in plasma progesterone concentrations, cloprostenol induced complete luteolysis in all hinds treated on days 8-16 and in five of six hinds treated on day 6 . Oestrus, ovulation and conception occurred in $25(69 \%), 28(78 \%)$ and $25(69 \%)$, respectively, of hinds treated on days $6-16$ inclusive $(n=36)$. Luteolysis was incomplete in all hinds treated on day 4 , and none of the animals exhibited oestrus or ovulated; luteolysis was incomplete for one hind treated on day 6 . Short luteal cycles $(<12$ days duration) occurred in six hinds following cloprostenol treatment, but this occurred only in hinds treated on day $6(n=3)$, day $8(n=1)$ or day $10(n=2)$. The mean intervals from injection of cloprostenol to onset of oestrus and peak preovulatory $\mathrm{LH}$ surge values were significantly shorter for hinds treated on day 6 or day $8(\sim 50 \mathrm{~h}$ and $52 \mathrm{~h}$ for oestrus and LH surges, respectively) than for those treated on days 10-16 inclusive ( $60 \mathrm{~h}$ and $65 \mathrm{~h}$, respectively) $(P<0.05)$. It is concluded that on day 4 of the cycle, the cervine corpus luteum is refractory to a single injection of the prostaglandin analogue, whereas on day 6 the corpus luteum is responsive in most animals, and that whereas corpora lutea at days 8-10 are responsive in all animals, a high incidence of subsequent premature luteal regression may occur. Fertility to cloprostenol-induced oestrus and ovulation following natural mating was high, especially for hinds treated on days 12, 14 and 16 of the oestrous cycle (i.e., $>80 \%$ conception rate).
\end{abstract}

\section{Introduction}

The cervid oestrous cycle has many similarities to that of other ruminants, exhibiting distinct follicular, luteotrophic and luteolytic phases (Asher and Fisher, 1991). There is considerable evidence implicating uterine secretion of prostaglandin $\mathrm{F}_{2 \alpha}$ $\left(\mathrm{PGF}_{2 a}\right)$ in the regression of the corpus luteum of the oestrous cycle in many species (Knickerbocker et al., 1988). Studies have

Received 25 August 1994. shown that spontaneous luteolysis in fallow deer (Dama dama) is associated with episodic release of uterine $\mathrm{PGF}_{2 \alpha}$ between day 16 and day 20 of the oestrous cycle (Asher et al., 1988). Characteristically, luteolysis involves a rapid decline in peripheral plasma progesterone concentrations, and oestrus and ovulation usually occur within 48-96 h (McCracken et al., 1970; Louis et al., 1974). The development of potent synthetic analogues of $\mathrm{PGF}_{2 \alpha}$ has enabled synchronization of oestrus to be performed in many domestic species by premature induction of luteal regression. Administration of prostaglandin analogues 
during the oestrous cycle induces luteolysis in a number of cervids including fallow deer (Asher and Thompson, 1989; Asher et al., 1990; Jabbour et al., 1993), red deer (Cervus elaphus scoticus; Asher et al., 1992; Fisher et al., 1994) and North American wapiti (Cervus elaphus nelsoni; Glover, 1985). However, efficacy of induction of luteolysis at different stages of the oestrous cycle is poorly defined for cervids. Studies in sheep, goats and cattle have shown that corpora lutea are refractory to the luteolytic influences of prostaglandin analogues before days 3-5 of the oestrous cycle (Rowson et al., 1972; Hearnshaw et al., 1974; Roche, 1974; Acritopoulou and Haresign, 1980). Preliminary studies on red deer and North American wapiti indicated that refractoriness may persist for longer in cervids, and corpora lutea at day 11 and day 9 can exhibit marked refractoriness in the two subspecies, respectively (Glover, 1985; Fisher et al., 1994).

The objective of the present study was to evaluate the efficacy of a prostaglandin analogue in inducing luteolysis in farmed red deer throughout the oestrous cycle, by assessing changes in progesterone secretion, the occurrence of oestrus and ovulation, and the level of fertility following oestrus induced by a single injection of cloprostenol, a synthetic prostaglandin. We also sought to define changes in progesterone secretion during spontaneous luteolysis by monitoring untreated hinds between day 16 and day 19 of a synchronized oestrous cycle.

\section{Materials and Methods}

\section{Animals and management}

A total of 48 mature (3-10 years old) red deer hinds at the Ruakura Agricultural Centre $\left(37^{\circ} 46^{\prime} \mathrm{S}, 175^{\circ} 20^{\prime} \mathrm{E}\right)$ were run in the continuous presence of one or more vasectomized stags from calf removal on 16 March until administration of prostaglandin analogue on 21 April. Thereafter, they were run with one or more fertile stags until 30 May. They were grazed on ryegrass-white clover pastures and offered supplements of meadow hay. Water was provided ad libitum.

\section{Experimental protocol}

Hinds were allocated, on the basis of livemass, to eight treatments $(n=6$ hinds per treatment with treatment average livemass of 96-97 kg). Oestrus of hinds was synchronized by intravaginal placement of a single CIDR (controlled internal drug releasing) device (CIDR-type G, $0.3 \mathrm{~g}$ progesterone per device; Agricultural Division, CHH Plastic Products Group Ltd, Hamilton) to each hind for 12 days, and the CIDR device was replaced on day 8. An i.m. injection of 250 iu pregnant mares' serum gonadotrophin (PMSG: Folligon; Intervet, Lane Cove, NSW) was administered at the time of removal of the second device to ensure successful induction of oestrus and ovulation (Fennessy et al., 1991). The regimen for synchronization of oestrus was staggered by intervals of 2 days between successive treatment groups to produce a range of subsequent luteal ages (4-16 days) on 21 April, at which time $500 \mu \mathrm{g}$ cloprostenol $(2.0 \mathrm{ml}$ Estrumate: Imperial Chemical Industries PLC, Wilmslow, Cheshire) was administered by i.m. injection to all but one group of hinds. Luteal ages at time of injection, defined as the interval from the synchronized oestrus (predicted to occur at around $48 \mathrm{~h}$ after removal of CIDR devices; Asher et al., 1992), were $4,6,8,10,12,14$ and 16 days. The remaining six hinds were synchronized with the last group and were at day 16 at the start of the intensive monitoring period.

\section{Collection of blood samples}

Blood samples were collected from all hinds by jugular venepuncture every second day from 20 March to 27 May. Additional jugular samples were collected every $6 \mathrm{~h}$ for $78 \mathrm{~h}$ from the time of administration of cloprostenol. The plasma samples were assayed for progesterone to assess changes in luteal status, and for $\mathrm{LH}$ to determine the incidence and time of onset of the preovulatory LH surge.

\section{Behavioural observations}

During the period of intensive collection of blood samples (21-24 April), observations to detect oestrus and mating were conducted continuously from an enclosed observation platform fitted with halogen floodlights. Identification of individual animals was possible using a monocular telescope $(\times 20)$. The hinds were run with single fertile stags during this period, and stags were replaced every $24 \mathrm{~h}$.

\section{Pregnancy determination}

Rectal ultrasonography (White et al., 1989; Wilson and Bingham, 1990) was performed 33 and 43 days after administration of cloprostenol to determine pregnancy status.

\section{Hormone assays}

Plasma concentrations of progesterone were determined in duplicate by the direct radioimmunoassay validated previously for red deer plasma (Asher et al., 1992). All samples from each hind were included within a single assay. Samples with low, medium and high concentrations of progesterone were included as control samples at frequent intervals in each assay. The interassay coefficients of variation were $17.6 \%$ for the low control (mean $0.45 \mathrm{ng} \mathrm{m}^{-1}$ ), $12.1 \%$ for the medium control (4.83 $\mathrm{ng} \mathrm{ml}^{-1}$ ) and 10.0\% for the high control $\left(9.90 \mathrm{ng} \mathrm{ml}^{-1}\right.$ ) samples, respectively. The intra-assay coefficients of variation were $14.3 \%, 8.9 \%$ and $6.7 \%$ for the three control samples, respectively. Sensitivity of the standard curve, defined as the first point that was significantly different from 0 , was $0.10 \mathrm{ng} \mathrm{ml}^{-1}$.

Plasma LH concentrations were determined in duplicate by the heterologous radioimmunoassay described for sheep plasma by Scaramuzzi et al. (1970) and validated for red deer plasma by Kelly et al. (1982) and Asher et al. (1992). The sheep pituitary LH preparation used for standards and iod-

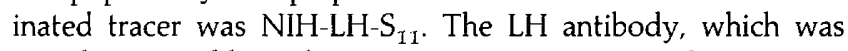
raised in a rabbit, also using NIH-LH-S ${ }_{11}$ as the antigen, was used in the assay at a final dilution of 1:200 000 . Crossreactivities with other proteins were described by Kelly et al. (1982). All samples from each hind were included within 
Table 1. Incidence of oestrus, a preovulatory LH surge, conception and short luteal cycles, and mean ( \pm SEM) times from cloprostenol treatment to the onset of oestrus and the LH peak for nonpregnant red deer hinds treated at various stages of the oestrous cycle

\begin{tabular}{|c|c|c|c|c|c|c|c|}
\hline Treatment & $\begin{array}{l}\text { Number } \\
\text { of hinds }\end{array}$ & $\begin{array}{c}\text { Number of } \\
\text { hinds exhibiting } \\
\text { oestrus }\end{array}$ & $\begin{array}{c}\text { Mean time } \\
(\mathrm{h} \pm \text { SEM) to } \\
\text { onset of oestrus }\end{array}$ & $\begin{array}{l}\text { Number of } \\
\text { hinds ovulating } \\
\text { (LH surge) }\end{array}$ & $\begin{array}{l}\text { Mean time } \\
(\mathrm{h} \pm \text { SEM }) \\
\text { to LH peak }\end{array}$ & $\begin{array}{l}\text { Number of } \\
\text { hinds conceiving } \\
\text { after induced } \\
\text { oestrus }\end{array}$ & $\begin{array}{l}\text { Number of } \\
\text { hinds exhibiting short } \\
\text { luteal phase at the cycle } \\
\text { following cloprostenol } \\
\text { administration }\end{array}$ \\
\hline Day 4 & 6 & 0 & - & 0 & - & 0 & 0 \\
\hline Day 10 & 6 & 4 & $59.3 \pm 3.8$ & 4 & $61.5 \pm 4.5$ & 4 & 2 \\
\hline Day 12 & 6 & 4 & $60.8 \pm 2.6$ & 4 & $64.5 \pm 2.9$ & 4 & 0 \\
\hline Day 14 & 6 & 5 & $60.6 \pm 3.6$ & 6 & $65.0 \pm 3.6$ & 5 & 0 \\
\hline Day 16 & 6 & 4 & $62.0 \pm 6.4$ & 5 & $66.0 \pm 5.0$ & 5 & 0 \\
\hline Untreated hinds* & 6 & 1 & - & 2 & - & - & - \\
\hline Total & 48 & 25 & $57.4 \pm 1.8$ & 30 & $60.2 \pm 2.0$ & 25 & 6 \\
\hline
\end{tabular}

*Day 16 at the start of intensive collection of blood samples.

a single assay. The interassay and intra-assay coefficients of variation for multiple determination of a cervine control sample (mean $5.40 \mathrm{ng} \mathrm{ml}^{-1}$ ) were $9.7 \%$ and $4.8 \%$, respectively, and the sensitivity of the standard curve was $0.03 \mathrm{ng}$ NIH-LH-S $\left(0.30 \mathrm{ng} \mathrm{ml}^{-1}\right)$. The upper limit of the assay was $15 \mathrm{ng} \mathrm{ml}^{-1}$, but samples exceeding this value were not reassayed following dilution as we required data on the incidence, rather than characteristics, of the preovulatory LH surge (after Asher et al., 1992).

\section{Statistical analyses}

Data on the intervals from treatment to the onset of oestrus and the LH surge, and plasma progesterone concentrations following administration of cloprostenol were analysed with respect to treatment day by analysis of variance (GENSTAT V; Lawes Agricultural Trust, Rothamsted Experimental Station). Means are presented with either the standard error of the mean (SEM) or standard error of difference (SED) based on pooled variance.

\section{Results}

\section{Oestrous and ovulatory responses}

Oestrus was observed for 24 of 42 (57\%) hinds within $78 \mathrm{~h}$ following administration of cloprostenol, and for 1 of 6 untreated hinds during the same observation period. The incidence of oestrus varied between treatments (Table 1), and no hinds treated on day 4 , and between 3 and 5 animals in other treatment groups (days 6-16), exhibited oestrus. A preovulatory LH surge (i.e. values $>10 \mathrm{ng} \mathrm{ml}^{-1}$ ) was observed within the same monitoring period for 28 of $42(67 \%)$ treated hinds and 2 of $6(33 \%)$ untreated hinds. A preovulatory LH surge was recorded in all hinds that exhibited oestrus. The incidence of surges again varied between treatments (Table 1 ), and no hinds treated on day 4 , and between 4 and 6 hinds in other treatment groups, exhibited a preovulatory LH surge. Mean ( \pm SEM) intervals from injection of cloprostenol to oestrus and the LH peak were $57.4 \pm 1.8 \mathrm{~h}$ and $60.2 \pm 2.0 \mathrm{~h}$, respectively. However, there was a significant effect of day of treatment, with oestrus/ovulatory hinds treated on day 6 or day 8 exhibiting shorter intervals than those treated on days 10-16 $(P<0.05$; Table 1). A total of 25 treated hinds conceived following mating at the induced oestrus/ovulation, representing between 3 and 5 pregnancies for hinds treated on days 6-16, inclusive, and none for hinds treated on day 4 or untreated hinds (Table 1). Analysis of profiles of plasma concentrations of progesterone for individual hinds indicates that six hinds exhibited short luteal cycles (i.e. < 12 days duration) following injection of cloprostenol, and the incidence of short cycles was restricted to hinds treated on day $6(n=3)$, day $8(n=1)$ or day $10(n=2)$ (Table 1$)$.

\section{Profiles of plasma progesterone concentrations}

Mean plasma concentrations of progesterone at the time of administration of cloprostenol (time 0 ) varied between treatments according to stage of luteal development, being between 2 and $3 \mathrm{ng} \mathrm{ml}^{-1}$ for days 4-8, inclusive, and 3.5 and $5.5 \mathrm{ng} \mathrm{ml}^{-1}$ for days 10-16 (Fig. 1). Administration of cloprostenol caused a rapid decline (i.e. $>50 \%$ reduction within $6 \mathrm{~h}$ ) in mean progesterone concentrations in all groups. However, all hinds treated on day 4 exhibited an apparent luteal recovery within the monitoring period, manifest as a progressive increase in mean concentrations after $36 \mathrm{~h}$, with values exceeding those of time 0 by $78 \mathrm{~h}$. Hinds in all other groups exhibited decreasing concentrations of progesterone throughout the monitoring period, and mean concentrations for each group remained below $1 \mathrm{ng} \mathrm{ml} \mathrm{ml}^{-1}$ from $18 \mathrm{~h}$ after injection. The exception to this was one 


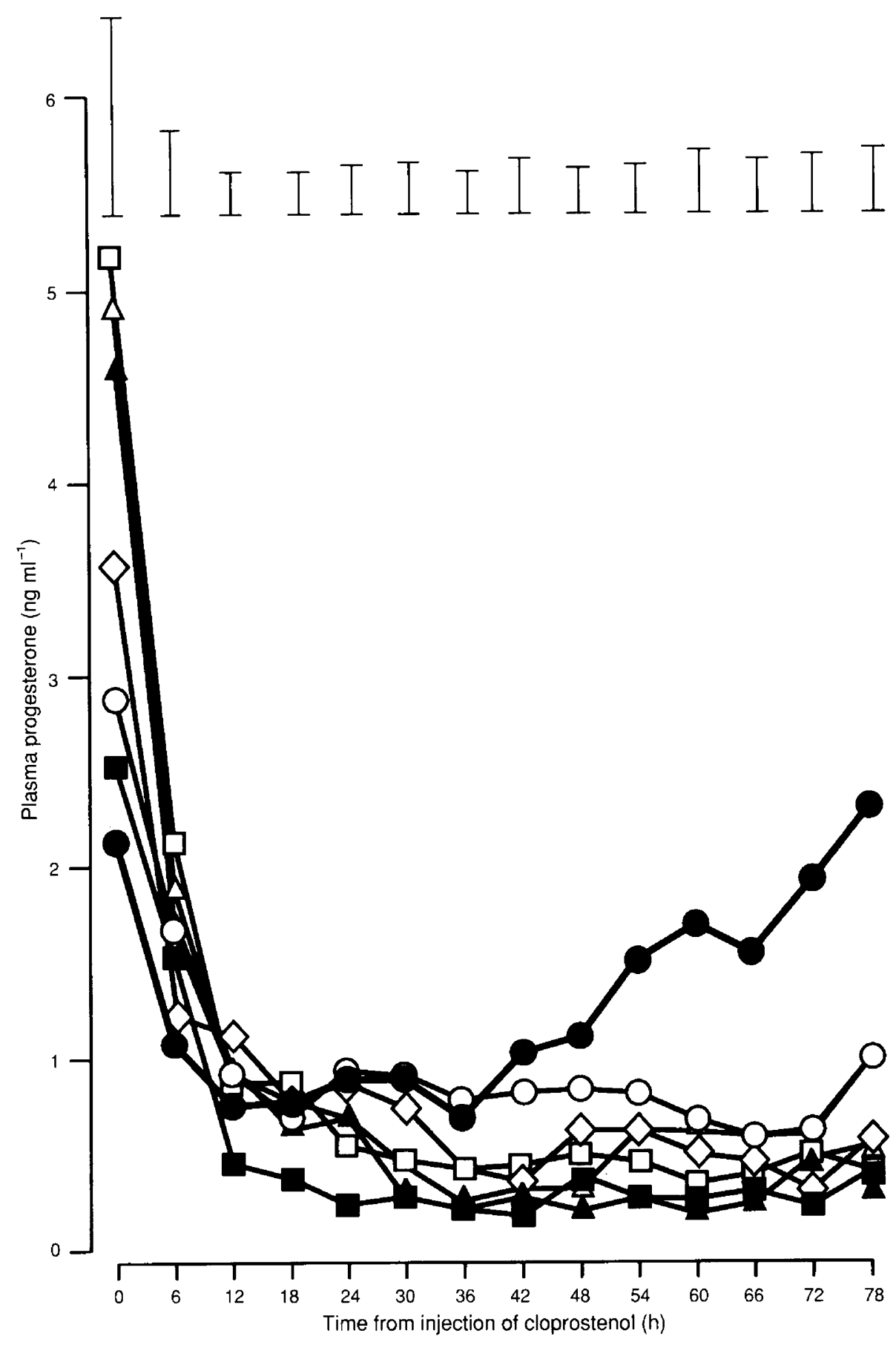

Fig. 1. Profiles of mean plasma concentrations of progesterone for red deer hinds treated with $500 \mu \mathrm{g}$ cloprostenol on days $4(\bullet), 6(\bigcirc), 8(\boldsymbol{\square}), 10(\square), 12(\boldsymbol{\Delta}), 14(\triangle)$ or $16(\diamond)$ of the oestrous cycle. Each profile represents the mean of six animals blood sampled every $6 \mathrm{~h}$ for $78 \mathrm{~h}$. Vertical bars represent SLD.

hind treated on day 6, which failed to exhibit oestrus or an LH surge and showed evidence of luteal recovery within $30 \mathrm{~h}$ of treatment (Fig. 2). Mean progesterone concentrations for hinds treated on day 4 were significantly higher than those of all other groups from $54 \mathrm{~h}$ after injection $(P<0.05$; Fig. 1).

Recovery of luteal progesterone secretion within $78 \mathrm{~h}$ of injection of cloprostenol was evident for hinds treated on day 4 , and a continued increase of mean values occurred over the next 8-10 days, followed by spontaneous luteolysis between 4 and 6 May (17-19 days from day 0) (Fig. 3). By contrast, luteolysis following injection of cloprostenol was demonstrably complete within $78 \mathrm{~h}$ for hinds treated on day 14, and 5 of 6 hinds conceived at the induced oestrus and exhibited increasing luteal progesterone secretion between 25 April and 3 May. Thereafter, mean plasma 


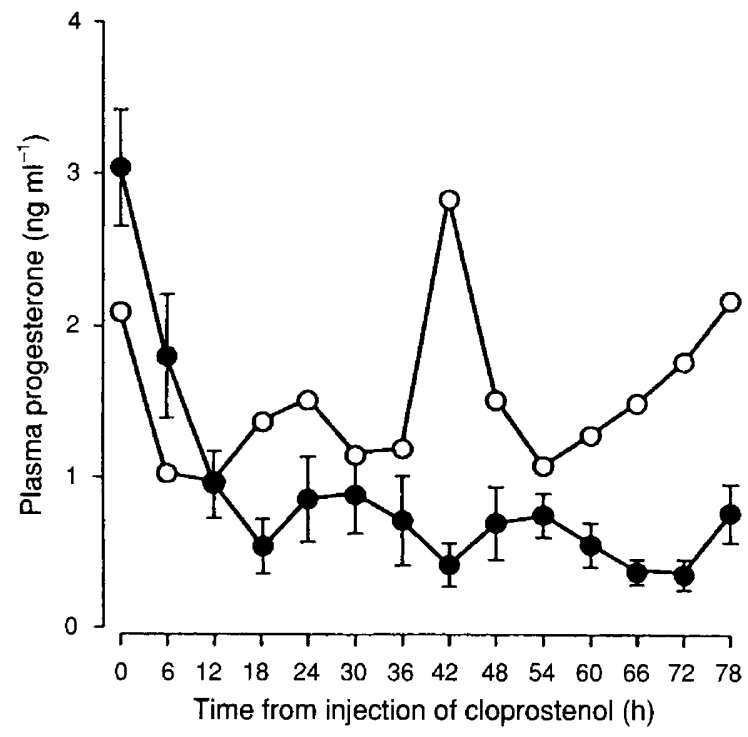

Fig. 2. Profiles of plasma concentrations of progesterone for red deer hinds treated with $500 \mu \mathrm{g}$ cloprostenol on day 6 of the oestrous cycle, showing the mean ( \pm SEM) concentrations for five hinds that exhibited oestrus or an LH surge, showing full luteal regression (-) and the individual profile for one hind that failed to exhibit either oestrus or an LH surge, and in which luteal regression did not occur $(O)$.

concentrations of progesterone fluctuated between 2 and $6 \mathrm{ng} \mathrm{ml}^{-1}$ (Fig. 3).

\section{Spontaneous luteolysis}

Untreated hinds were predicted to be at day 16 of the oestrous cycle at the start of the $78 \mathrm{~h}$ intensive blood sampling regimen (that is, time 0). Five of these hinds exhibited spontaneous luteolysis during the monitoring period (days 16-19), and the mean concentrations of plasma progesterone declined progressively from $3.5 \mathrm{ng} \mathrm{ml} \mathrm{ml}^{-1}$ (time 0 ) to $0.3 \mathrm{ng} \mathrm{ml}^{-1}$ by $60 \mathrm{~h}$ (Fig. 4). The hind that failed to exhibit luteolysis during this period displayed high concentrations of plasma progesterone $\left(2.9-4.7 \mathrm{ng} \mathrm{ml}^{-1}\right)$ throughout the monitoring period (Fig. 4), but appeared to have undergone complete luteolysis $48 \mathrm{~h}$ later (25 April).

\section{Discussion}

The study reported here indicates that, for red deer, the corpus luteum is refractory to the luteolytic action of a single injection of $500 \mu \mathrm{g}$ cloprostenol when administered on day 4, largely responsive on day 6 and fully responsive by day 8 after oestrus, as evidenced by changes in plasma concentrations of progesterone. Hinds treated on day 4 exhibited an initial decline in progesterone secretion over the $24 \mathrm{~h}$ after cloprostenol delivery. However, there was an apparent rebound in luteal activity as progesterone concentrations were restored to pretreatment values and most hinds failed to exhibit oestrus. In contrast, most hinds ( 5 of 6 ) treated on day 6 and all hinds treated on days 8-16 underwent complete luteolysis, and plasma progesterone concentrations remained below
$0.5 \mathrm{ng} \mathrm{ml}^{-1}$ from 48 to $78 \mathrm{~h}$ after cloprostenol delivery. Furthermore, most of these hinds were observed in oestrus or exhibited a preovulatory LH surge within $78 \mathrm{~h}$. In these respects, the responsiveness of red deer hinds to exogenous prostaglandins in this study was similar to that observed for sheep (Acritopoulou and Haresign, 1980), goats (Hearnshaw et al., 1974) and cattle (Rowson et al., 1972; Roche, 1974); all of these species tended to exhibit full luteolytic responses if treated on or after day 5 of the oestrous cycle.

It should be noted that the data from the present study conflict with earlier studies on red deer (Fisher $e t$ al., 1994) and North American wapiti (Glover, 1985), both of which demonstrated a marked degree of refractoriness to a prostaglandin analogue when administered on days 9-11 of the oestrous cycle of monovulating females. The different luteolytic responses of hinds in the two red deer studies (Fisher et al., 1994; present study) are most likely the result of subtle variations in luteotrophic support of the corpus luteum reflecting differences between regions (the two studies were conducted $1000 \mathrm{~km}$ latitude apart) and years. Although initial synchronization treatments were conducted at similar times of the year (late March-early April), subtle differences in timing relative to spontaneous reproductive activity (i.e. the rut) between years and regions may have occurred, resulting in differences in hypothalamic-pituitary support of the corpora lutea. Macmillan et al. (1985a, b) and Henderson and McNatty (1977) reported that pituitary support of the corpus luteum in other species determines the sensitivity of luteal tissue to the luteolytic effects of endogenous or exogenous prostaglandin. It would be reasonable to assume that reduced luteotrophic support renders cervine corpora lutea more sensitive to the luteolytic effects of prostaglandins. The issue of refractoriness in red deer requires further clarification if prostaglandins are to be used for induction of luteolysis without reference to stage of the oestrous cycle.

The intervals from the time of administration of cloprostenol to the onset of oestrus and the preovulatory LH surge were shorter for hinds treated on day 6 and day 8 than for hinds treated later in the oestrous cycle. This probably arises from a more rapid reduction in progesterone secretion to basal concentrations as a consequence of lower initial luteal activity at the time of injection. A similar phenomenon is apparent from the data of Acritopoulou and Haresign (1980) for sheep, although overall the intervals at all stages of the oestrous cycle were shorter for sheep than for red deer (e.g. $37 \mathrm{~h}$ versus $57 \mathrm{~h}$ to onset of oestrus). Similarly, the interval from cloprostenol injection to onset of oestrus for fallow deer treated on day 13 of their oestrous cycle was shorter (i.e. 48 h) than that observed for red deer (Asher and Thompson, 1989). Reasons for variation between species remain to be resolved.

The occurrence of short luteal cycles in some hinds following cloprostenol treatment on days $6-10$ is similar to the phenomenon observed following administration of prostaglandin to sheep (Schiewe et al., 1990). Premature luteal regression was restricted to hinds treated early in the oestrous cycle, supporting the suggestion that transient corpora lutea are a result of insufficient duration of progesterone priming before the induction of luteolysis. As a consequence of the incidence of short luteal cycles in red deer hinds, fewer individuals treated between day 6 and day 10 are likely to 


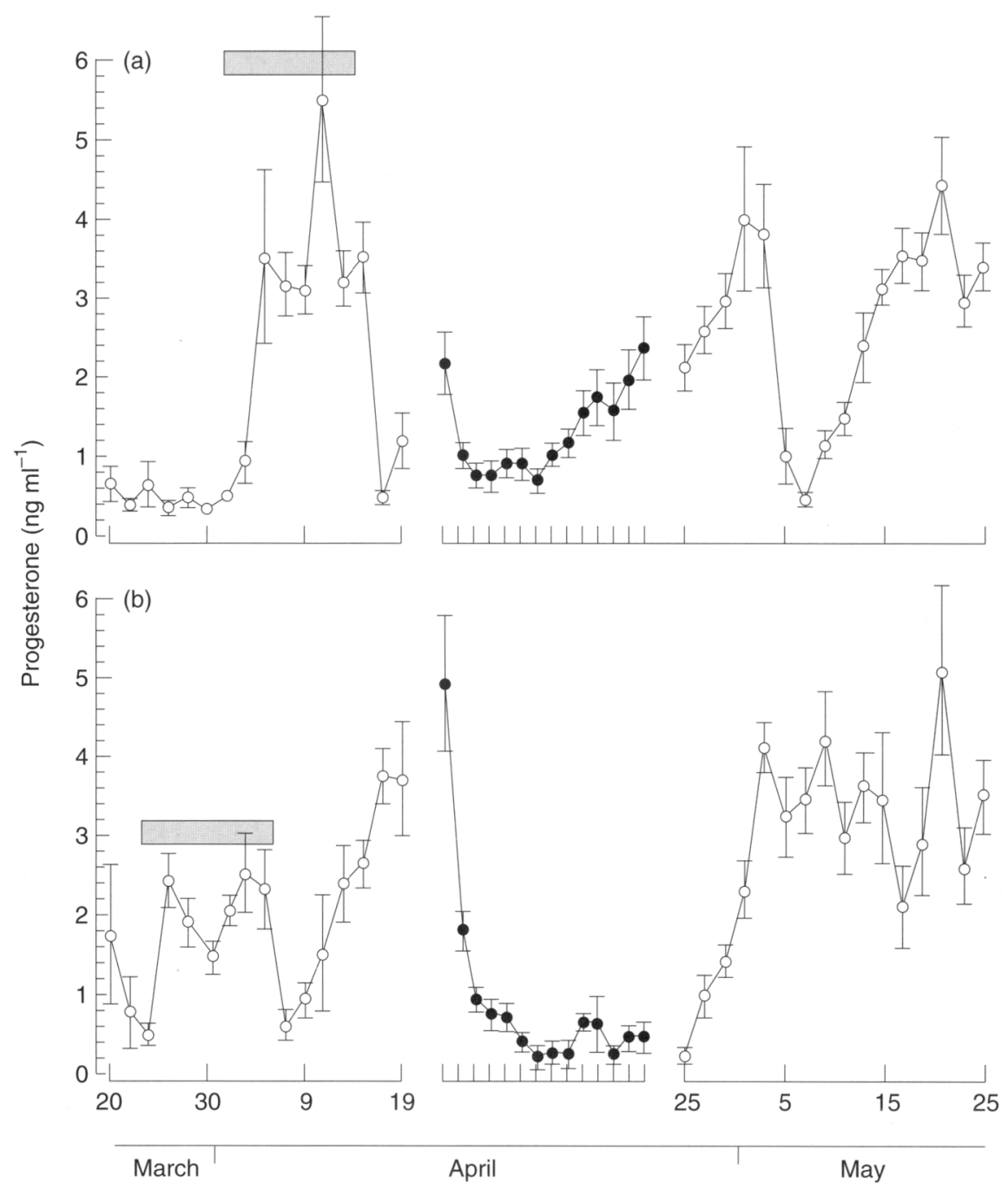

Fig. 3. Longitudinal profiles of mean ( \pm SEM) plasma concentrations of progesterone for red deer hinds treated with $500 \mu \mathrm{g}$ cloprostenol on (a) day 4 and (b) day 14 of the oestrous cycle. Mean values for blood samples collected at intervals of $6 \mathrm{~h}$ for $78 \mathrm{~h}$ from cloprostenol injection on 21 April are represented by solid symbols. The shaded bar represents the period of treatment with intravaginal controlled internal drug releasing (CIDR) devices.

conceive as a result of induced oestrus and ovulation than those treated after delivery of prostaglandins later in the cycle. This was the case in the present study. On the basis of this observation, and given the apparent complete refractoriness to prostaglandins on day 4 , it would seem that effective practical use of exogenous prostaglandins to induce fertile oestrus and ovulation in red deer hinds should be confined to later stages of the oestrous cycle (i.e. days 12-16). This finding supports earlier suggestions that application in red deer without reference to known stages of the oestrous cycle necessitates delivery of two injections of prostaglandins 10-12 days apart (Fennessy et al, 1989).

In the study reported here, in which hinds were placed with two fertile stags immediately after delivery of cloprostenol, fertility was surprisingly high. In all, 25 of the 42 treated hinds became pregnant $(60 \%)$. However, if one excludes hinds treated on day 4 (i.e. no oestrous and ovulatory response to treatment) and the six hinds that exhibited short luteal cycles in response to treatment, $83 \%$ of remaining hinds conceived as a result of induced ovulation. Such high fertility (which approaches conception rates following natural mating to progesteronesynchronized oestrus; Fennessy et al., 1991) was unexpected because of studies on fallow deer that demonstrated reduced fertility of does with cloprostenol-induced ovulation relative to those exposed to other forms of synchronization (Asher et al., 1992; Jabbour et al., 1993).

Spontaneous luteolysis occurred in five of six untreated hinds between day 16 and day 19 , which is in accord with the known duration of the oestrous cycle (18 days) for red deer (Guinness et al., 1971; Adam et al., 1985). In general, reductions in plasma concentrations of progesterone for these hinds proceeded at slower rates than for hinds receiving a single injection of cloprostenol, with indications for some hinds that spontaneous luteolysis may have been initiated before the start of intensive collection of blood samples on day 16. Only one untreated hind was observed in oestrus, and only two Downloaded from Bioscientifica.com at 04/26/2023 08:39:15AM 


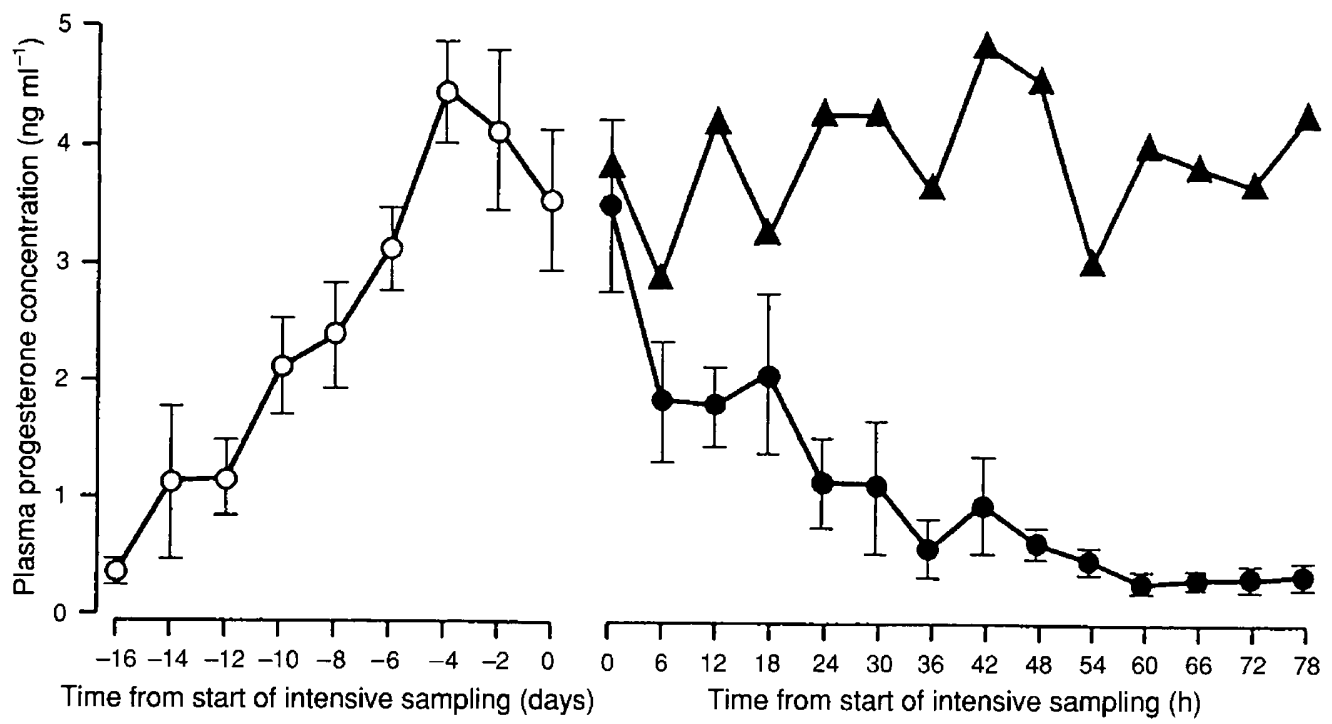

Fig. 4. Profiles of mean ( \pm SEM) concentrations of plasma progesterone for six untreated red deer hinds during the oestrous cycle, including data for blood samples collected every second day from removal of CIDR devices (O) and every $6 \mathrm{~h}$ for $78 \mathrm{~h}$ from day 16 of the oestrous cycle (21 April) for five hinds exhibiting spontaneous luteolysis $(\mathbf{O})$ and one hind that failed to initiate luteolysis $(\boldsymbol{\Delta})$.

untreated hinds exhibited a preovulatory LH surge during the $78 \mathrm{~h}$ of intensive blood sampling, even though luteolysis appeared to be complete in most individuals by $60 \mathrm{~h}$. This finding indicates a general lack of synchrony relative to treated hinds. With respect to the pattern of progesterone secretion, spontaneous luteolysis was similar to that observed in fallow deer (Asher et al, 1988).

In summary, the luteolytic response to the prostaglandin analogue in red deer from about day 6 of the oestrous cycle is in accord with that reported for other ruminant species but conflicts with other studies in red deer, which have indicated refractoriness as late as days 9-11. Levels of synchronization and fertility observed in the study reported here indicate considerable potential for practical application of induced luteolysis for artificial breeding of red deer, and administration of cloprostenol between day 12 and day 16 was particularly promising.

The authors thank the staff of the Ruakura Deer Unit for their valued assistance during these studies.

\section{References}

Acritopoulou S and Haresign W (1980) Response of ewes to a single injection of an analogue of PGF-2 $\alpha$ given at different stages of the oestrous cycle Journal of Reproduction and Fertility $\mathbf{5 8} 219-223$

Adam CL, Moir CE and Atkinson T (1985) Plasma concentrations of progesterone in female red deer (Cervus elaphus) during the breeding season, pregnancy and anoestrus Journal of Reproduction and Fertility 74 631-636

Asher GW and Fisher MW (1991) Reproductive physiology of farmed red deer (Cervus elaphus) and fallow deer (Dama dama). In Wildlife Production: Conservation and Sustainable Development pp 474-484 Eds LA Renecker and RJ Hudson. AFES Publication, University of Alaska, Fairbanks

Asher GW and Thompson JGE (1989) Plasma progesterone and LH concentrations during oestrous synchronization in female fallow deer (Dama dama) Animal Reproduction Science 19 143-153
Asher GW, Peterson AJ and Watkins WB (1988) Hormonal changes during luteal regression in farmed fallow deer, Dama dama Journal of Reproduction and Fertility 84 379-386

Asher GW, Fisher MW, Smith JF, Jabbour HN and Morrow CJ (1990) Temporal relationship between the onset of oestrus, the pre-ovulatory LH surge and ovulation in farmed fallow deer, Dama dama Journal of Reproduction and Fertility $89761-767$

Asher GW, Fisher MW, Jabbour HN, Smith JF, Mulley RC, Morrow CJ, Veldhuizen FA and Langridge M (1992) Relationship between the onset of oestrus, the preovulatory surge of luteinizing hormone and ovulation following oestrous synchronization and superovulation of farmed red deer (Cervus elaphus) Journal of Reproduction and Fertility 96 261-273

Fennessy PF, Fisher MW and Asher GW (1989) Synchronisation of the oestrous cycle in deer Proceedings of a Deer Course for Veterinarians (Deer Branch, New Zealand Veterinary Association) 6 29-35

Fennessy PF, Mackintosh CG, Shackell GH and Whaanga AJ (1991) Artificial insemination and synchronised natural bleeding in red deer Proceedinzs of the New Zealand Society of Animal Production 51 327-331

Fisher MW, Asher GW, Meikle LM and Newman RE (1994) Cloprostenolinduced luteolysis in the red deer hind: the effects of age, dose, number of corpora lutea and the later stages of the oestrous cycle Animal Reproduction Science 35 99-109

Glover GJ (1985) Aspects of the Reproductive Physiology of Female Wapiti MSc Thesis, University of Saskatchewan

Guinness FE, Lincoln A and Short RV (1971) The reproductive cycle of the female red deer, Cervus elaphus journal of Reproduction and Fertility 27 $427-438$

Hearnshaw M, Restall BJ, Nancarrow CD and Mattner PB (1974) Synchronization of oestrus in cattle, sheep and goats using a prostaglandin analogue Proceedings of the Australian Society of Animal Production 10 242-245

Henderson KM and McNatty KP (1977) A possible interrelationship between gonadotrophin stimulation and prostaglandin $\mathrm{F}_{2 a}$ inhibition of steroidogenesis by granulosa luteal cells in vitro Journal of Endocrinology $73 \quad 71-78$

Jabbour HN, Veldhuizen FA, Green G and Asher GW (1993) Endocrine responses and conception rates in fallow deer (Dama dama) following oestrous synchronisation and cervical insemination with fresh or frozen-thawed spermatozoa Journal of Reproduction and Ferility 98 495-502

Kelly RW, McNatty KP, Moore GH, Ross D and Gibb M (1982) Plasma concentrations of $\mathrm{LH}$, prolactin, oestradiol and progesterone in female red deer (Cerous elaphus) during pregnancy Joumal of Reproduction and Fertility 64 $475-483$

Knickerbocker MC, Wiltbank MC and Niswender GD (1988) Mechanisms of luteolysis in domestic livestock Domestic Animal Endocrinology 5 91-107 
Louis TM, Hafs HD and Morrow DA (1974) Intrauterine administration of prostaglandin $\mathrm{F}_{2 u}$ in cows: progesterone, estrogen, $\mathrm{LH}$, estrus and ovulation Journal of Animal Science 38 347-353

McCracken JA, Glew ME and Scaramuzzi RJ (1970) Corpus luteum regression induced by prostaglandin $\mathrm{F}_{2 \alpha}$ Journal of Clinical Endocrinology and Metabolism $30544-546$

Macmillan KL, Day AM, Taufa VK, Gibb M and Pearce MG (1985a) Effects of an agonist of gonadotrophin releasing hormone in cattle. l. Hormone concentrations and oestrous cycle length Animal Reproduction Science 8 203-212

Macmillan KL, Day AM, Taufa VK, Peterson AJ and Pearce MG (1985b) Effects of an agonist of gonadotrophin releasing hormone in cattle. II. Interactions with injected prostaglandin $\mathrm{F}_{2 \alpha}$ and unilateral ovariectomy Animal Reproduction Science 8 213-223

Roche JF (1974) Synchronization of oestrus and fertility following artificial insemination in heifers given $\mathrm{PGF}_{2 u}$ Journal of Reproduction and Fertility 37 $135-138$
Rowson LEA, Tervit R and Brand A (1972) The use of prostaglandins for synchronization of oestrus in cattle Journal of Reproduction and Fertility 29 145 (Abstract)

Scaramuzzi RJ, Caldwell BV and Moor RM (1970) Radioimmunoassay of LH and estrogen during the estrous cycle of the ewe Biology of Reproduction 3 $110-119$

Schiewe MC, Howard JG, Goodrowe KL, Stuart LD and Wildt DE (1990) Human menopausal gonadotropin induces ovulation in sheep, but embryo recovery after prostaglandin $\mathrm{F}_{2 u}$ synchronization is compromised by premature luteal regression Theriogenology 34 469-486

White IR, McKelvey WAC, Bushby S, Sneddon A and Hamilton WJ (1989) Diagnosis of pregnancy and prediction of foetal age in red deer by real-time ultrasonic scanning Veterinary Record 124 395-397

Wilson PR and Bingham CM (1990) Accuracy of pregnancy diagnosis and prediction of calving date in red deer using real-time ultrasound scanning Veterinary Record 126 133-135 